https://doi.org/10.38129/Ann.Yur.Ist.2020.4.4.69

УДК [323.2:34] (477) «16-17»

\title{
КОЗАЦЬКЕ ПРАВО ГЕТЬМАНЩИНИ ЯК ОСОБЛИВИЙ ПОЛІТИКО-ПРАВОВИЙ ФЕНОМЕН ${ }^{1}$
}

\author{
ВОЛОДИМИР МАКАРЧУК (Львів, Україна) * \\ ІВАН ТЕРЛЮК (Львів, Україна) *
}

Постановка проблеми. Навчальна дисципліна «Історія держави і права України» є загальнообов'язковою для вивчення у закладах вищої освіти держави. Навіть побіжний перегляд сторінок будь-якого підручника чи посібника говорить про те, що під «Україною» тут розуміється їі географічна територія, а під «правом України» - ті правові норми, які діяли на цій території у тому чи іншому часовому проміжку. У цьому розумінні «правом України» виступає й право античних міст-колоній, $\mathrm{i}$ «Свод законов Российской империи» і навіть розпорядження німецьких окупаційних властей у 1941-1944 рр. чи «правотворчість» сепаратистських утворень Л/ДНР. Зрозуміло, що в силу переривання або відсутності власної української державності більшість діючих на території України правових норм історично нав'язувалися державамизавойовниками, відтак мало відповідали менталітету місцевого українського населення, його уявленням про «право» і «справедливість». Тобто ситуація тут нагадує відоме російське прислів' я «Без меня меня женили».

Натомість у загальному пулі «права України», як його невід'ємна складова виділяється й власне «українське право», тобто створене українською політичною елітою з врахуванням українського менталітету. Безпосередніми творцями норм «українського права» могли виступати й етнічні не-українці, як-от представник онімеченого чеського роду Пилип Орлик чи етнічний єврей Володимир Зеленський, за чиїм підписом, відповідно до результатів всенародного волевиявлення 2019 р., наразі видаються Укази Президента

\footnotetext{
${ }^{1}$ Стаття надійшла до редакції 24 грудня 2019 р. У подальшому окремі положення, висловлені нижче, використовувались авторами в інших наукових публікаціях. Зважаючи на актуальність сформульованих тез і необхідність актуалізації козацького права саме як особливого політико-правового явища, головний редактор прийняв рішення підписати до друку цей першопочатковий варіант статті. - НРР.
} 
України. Відтак головними кваліфікаційними ознаками «українського права» вважаємо його самостійність (що не виключає адаптованих запозичень 3 правової спадщини розвинутих народів) та вiдповiдність правовим ідеалам ma уявленням більшої частини місцевого українського населення як політичної нації. Третьою ознакою українського права пропонуємо вважати його прив'язаність до території України. У цьому розумінні «Руська правда» не може формально вважатися «українським правом», а виступає правом Київської Русі, чиї географічні межі охоплювали сучасні російські, білоруські, польські та ін. (для прикладу, Юр'єв - Тарту) території.

Мета дослідження. Охарактеризувати процес зародження власне українського права, його первісну (споконвічну) відмінність від права сусідніх держав - польського, московського, османського тощо.

Стан дослідження. 3-поміж грунтовної історіографії української козаччини, де переважають праці переважно «นистих» істориків (В. Брехуненко, В. Горобець, О. Гуржій, Ю. Мицик, В. Смолій, В. Степанков, Г. Стороженко, В. Шевчук, Т. Чухліб, В. Щербак та ін.), рідше істориків права (І. Бойко, І. Грозовський, А. Козаченко, О. Кресін, І. Паньонко, І. Усенко та ін.), досліджень 3 проблем козацького права загалом порівняно небагато. Серед праць, присвячених козацькому праву Гетьманщини, передовсім, виділяються розвідки з проблем вивчення окремих його галузей (напр., І. Бойко) та кодифікаційного процесу (напр., А. Яковлів чи В. Кульчицький). Чи не «найсвіжіша» публікація 3 проблем козацького права Гетьманщини присвячена питанням формування правової системи Гетьманщини з позицій не лише позитивізму, а й «jus naturale», тобто права природного². Утім, на наш погляд, в означеній проблематиці ще залишається чималий інтелектуальний ресурс.

Виклад основного матеріалу. Зазвичай у науковій та навколо-науковій літературі, під поняттям «козацьке право» розуміють систему звичаєво-правових норм, що сформувалися на Запорозькій Січі ${ }^{3}$, а згодом набули ознак

2 Шевчук Л., Шевчук Т. Основоположні засади та чинники формування національної правової системи Української козацької держави - Гетьманщини. Право України. 2020. № 1. С. 140-158.

${ }^{3}$ Грозовський I. Козацьке право. Право Украӥни. 1997. № 6. С. 76-80 та Кульчицький В. Козацьке право. Довідник з історії Украйни (А-Я) / за ред. І. Підкови, Р. Шуста. К.: Генеза, 2001. С. 324-325. 
«історичного типу українського звичаєвого права» ${ }^{4}$, й навіть стали чинником самоідентифікації українців (точніше, протоукраїнців, «руського» населення України - Abm.) XVII-XVIII століття5, що ліг в основу регулювання суспільних відносин у просторі «Козацької держави».

Остання, з нашого погляду, - цивілізаційне явище історії українського народу, масштабна наукова категорія, у широкому значенні - грандіозний шар історичної пам'яті народу, важливий період еволюції української держави як на ідеологічному, так і на інституційному рівні. У найширшому розумінні «Козацька держава» (i, відповідно, іii, спершу неписане, а згодом і писане право - Abm.) охоплює усі козацькі утворення, що почергово чи паралельно існували на території сучасної України XVI - останньої чверті XVIII ст.: Запорозьку Січ, реєстрові козацькі полки Речі Посполитої, Гетьманщину (від становлення середини XVII ст. і до знищення у 80-ті рр. XVIII ст.), Слобідські козацькі полки, Задунайську Січ. Усіх їх об'єднували спільні принципи та своєрідна система цінностей в облаштуванні суспільного життя, що засновувалися на ідеях свободи, справедливості, рівноправності та громадського інтересу.

Побіжно відмітимо й те майже ігнороване сучасними дослідниками питання, ту обставину, що козацька верства засадничо формувалася як інтернаціональна, а шлях на Січ був відкритий не тільки для місцуевих украйнців (за тодішнъою термінологією - «руських людеиј»), але й «поляків, литовизі, білорусів, великоросів, дониів, болгар, волохів, чорногориів, турків, татар, євреї, калмиків, німиів, фрранцузів, італіӥців, іспанців, англійців» 6. Тож козацький менталітет формувався не стільки на вузьконаціональній основі, скільки на визнанні суспільної иінності свободи, економічної самостійності і власної гідності як невід'ємної ознаки козака, вільної ююдини, яка володіє зброєю і готова відстоювати свої права навіть изіню власного життя.

Разом 3 тим «козацьке право» розглядалося як право-привілей - за аналогією з шляхетським правом. Подібно до т. зв. околичної або ходачкової шляхти, козак був особисто вільним дрібним власником і виробником, який стояв осторонь феодально-кріпосницької системи. Проте, на відміну від шляхетської верстви, козак був принципово ворожий феодальнокріпосницькій системі, а відтак виступав соціальним ідеалом для переважної

${ }^{4}$ Бедрій М. М. Козацьке право як історичний тип українського звичаєвого права (XVI - 40 рр. ХІХ ст.). Вісник Лъвівського університету. Серія юридична. 2015. Випуск 61. С. 78-86.

${ }^{5}$ Кушинська Л.А. Козацьке звичаєве право як чинник самоідентифікації українців XVII - XVIII століття. Економіка і право. 2015. Випуск 28. С. 104-111.

6 Яворнищький Д. І. Історія запорізьких козаків. Том І. - Львів: Світ, 1990. С. 115. 
маси поневоленого населення України. Підтвердженням впливу козаків став стихійний процес покозачення населення, що інтенсивно розгортався зокрема протягом XVII ст., й полягав у самовільному набутті козацьких прав представниками селян, міщан, шляхти - вихідців з усіх тих соціальних груп, хто поділяв «козацьку фрілософрію».

Останні сплески самовільного покозачення фіксуємо під час війни Росії 3 Наполеоном (1812 р.) та у ході Визвольних Змагань 1917-1921 pр.

Загалом, у період Козаччини відбувалися процеси, які власне визначили особливості формування i розвитку новочасної Української Держави, паралельно - також українського націогенезу.

Постання Гетьманщини під офіційною назвою - Військо Запорозьке, стало апогеєм в розвитку Козацької держави й одним із найважливіших результатів Національної революції українського народу середини XVII ст. Революційний характер подій української історії, які розпочалися під керівництвом гетьмана Б. Хмельницького у 1648 р. (відомі ще як «Хмельниччина» - Abm.) й засвідчили становлення нової форми української державності, тривали до ліквідації восени 1676 р. козацьких державних інституцій гетьмана Петра Дорошенка у Правобережній Україні. Ця теза найпослідовніше обстоюється та найгрунтовніше аргументується у працях провідних вітчизняних ученихмедієвістів В. Смолія та В. Степанкова ${ }^{7}$. Зусиллями згаданих дослідників сучасна вітчизняна історична наука дійшла висновку, що подіï 1648-1676 pp. становили ланки єдиного процесу боротьби українського народу за створення національної держави, і1і незалежність і територіальну цілісність а також боротьби проти феодалізації суспільства, за утвердження нової моделі соціально-економічних відносин та нової якості українського права як права національного.

Сучасні вітчизняні науковці (на відміну від польських та російських колег XVII ст. - поч. XXI ст.) для визначення подій 1648-1654 рр. звично послуговуються терміном «Революція», оскільки в роки національновизвольної боротьби на території Війська Запорозького було здійснено кардинальні зміни в суспільному ладі, що передусім зумовлювалися змінами у формах феодального землеволодіння; у соціальній структурі українського

7 Смолій B., Степанков В. Богдан Хмельницький. Соціально-політичний портрет. К.: Наукова думка, 1993. 624 с.; Смолій B.A., Степанков В.С. Українська національна революція XVII ст. (1648-1676 рр.). К.: Альтернативи, 1999352 с.; Смолій В., Степанков B. Інститут влади в політичній системі України (середина - друга половина XVII ст.). К.: Наукова думка, 2014. - 244 с. 
суспільства, що насамперед значливо позначилися на правовому становищі окремих соціальних груп тодішніх українців. Було запроваджено вагомі переміни у судовому устрої, що полягали, зокрема, у ліквідації станових «статутових» судів, та у праві. Була ця Революція й «Національною», оскільки вказані зміни об'єктивно відповідали інтересам усіх соціальних прошарків українського народу, за винятком відносно вузької спольщеної верхівки.

Революційні за своїм характером зрушення у праві часів Хмельниччини, що мали за основу конститутивні перетвори в суспільному ладі, започаткували новий етап розвитку козацького права. Иого головним змістом стала втрата колишньої корпоративності й набуття ознак загального українського, національного права. Цьому значною мірою сприяли процеси масового покозачення недавніх селян-кріпаків та мішаного у національному відношенні населення міст (за винятком єврейської меншини).

3 нашого погляду, нова якість українського козацького права як права національного - на противагу колишньому корпоративному - виявлялася у низці таких ознак:

По-перше, перетворення звичаєвого козацького права Запорозької Січі разом зі звичаєвим (копним) правом окремих земель у суто національне, загальне право козацької Гетьманщини, а відтак - у козацьке право України, що означало те, що воно стає «юридичним підгрунтям для реалізації українським народом права на самовизначення шляхом розбудови власної державності» 8 й невід'ємною складовою тогочасного українського державотворення. Проте важливіше інше. Сам факт того, що норми козацького, донедавна корпоративного, права відтоді стали поширюватися на усі верстви населення підконтрольної гетьманській адміністрації території, включаючи й представників національних меншин, насправді засвідчив постання нової реальності, цивілізаційний вибір практично усіх суспільних верств тодішніх мешканців звільнених від польського феодального гніту земель, а не лише козаків, на користь закріплення у їхньому житті основних засад «козацької філософії».

По-друге, саме у цей історичний період внесено вагомі зміни до корпусу джерел права та у розвиток правових інституцій. Зокрема, більшість джерел права, які функціонували в Україні в період ії перебування у складі Речі Посполитої, на визволених землях було скасовано. Це, насамперед, стосувалося різних постанов королівської влади та сеймів, «Устави на волоки» (1557), «Ординації Війська Запорозького реєстрового» (1638) та інших актів, які

${ }^{8}$ Бедрій М. М. Зазнач. праця. С. 82. 
утверджували панування польської шляхти та магнатів, католицької церкви і польської влади.

Разом 3 тим, Національна революція українців середини XVII ст. формально не скасувала окремі нормативні акти права попереднього періоду: Литовський Статут 1588 року, збірники Магдебурзького права, «Саксонське зерцало», «Порядок прав...» Б. Гроїцького тощо. Деякий час у судовій практиці на них навіть не посилалися, не кажучи уже про безпосереднє (пряме) застосування. Це, з одного боку, дозволяє стверджувати, що у період Хмельниччини фактично не діяли найбільш принципові положення цих актів, де, зокрема, йшлося про прикріплення селян, перехід в інші стани і т. ін. А 3 іншого - дозволяє говорити про певну наступність правової традиції.

По-третє, зазначені процеси сприяли трансформації соціальної сутності права9 . Себто, кардинально змінилася соціальна свідомість народних мас щодо таких важливих для правосвідомості етносу понять як «справедливість», «моральність», «добро», «зло» і т. ін. Це проявлялося у формуванні нових норм у праві. Вони, серед іншого, стосувалися таких важливих, часто дражливих, правових інституцій життєдіяльності суспільства як земельна власність й володіння, станова приналежність, козацьке самоврядування, обсяг «послушенства» (повинностей - Abm.) селян тощо. Нові норми права свідчили про домінування природно-правових поглядів на право, й загалом відповідали українському правовому менталітету, В основі якого - індивідуалізм 10 и узагалі людиноценттичність, а також прото-лібертаріанські й навіть анархістські підходи. Тобто у правотворення закладалися засади, коли право пов'язували насамперед не 3 державою, а з людиною, суспільством, із тим, що його норми обумовлені природою людини, ії суспільним буттям. Для своєї історичної епохи та географічного регіону (між шляхетською Річчю Посполитою, Московською автократичною монархією та такою ж автократичною Османською імперією, «васалом» якої виступало Кримське ханство) це було небувале, у певному сенсі навіть «неможливе» явище. У цьому сенсі варто погодитися з Л. Кушинською, яка стверджувала, що саме XVII-XVIII столітmя можна вважати часом усвідомлення україниями своїх чітких національних відмінностей, визначним чинником формування яких було козачьке звичаєве право 11.

\footnotetext{
9 Терлюк I. Я. Держава і право в Україні: Сторінки історії. Львів: Сполом, 2008. С. 81.

10 Павловська-Кравчук В. Український правовий менталітет: Особливості становлення і розвитку. Вісник академії правових наук України. 2012. № 2 (69). С. 277-286.

11 Кушинська Л. А. Зазначена праця. С. 107.
} 
По-четверте, виникли нові джерела права - законодавчі акти, що їх видавала гетьманська влада. Оскільки козацьке право надавало великого значення регулюванню владних відносин, то у період Національної революції зростала питома вага тієі його частини, що регулювала передусім полковосотенну систему управління. Норми козацького права проникали у такі важливі сфери життя, як адміністративна, судова та кримінально-правова.

По-n'яте, характер будівництва української гетьманської держави в перебігу революції, як це не дивно, найбільше позначився на врегулюванні кримінально-правових відносин. Спрощувалася система злочинів і покарань. Із кола злочинів вилучалася низка діянь, що втратили актуальність за нових умов, як-то замахи на королівську владу та магнатсько-шляхетський порядок управління, зумисні та не зумисні дії щодо католицької церкви та віри тощо. Натомість з'явилися нові склади злочинів: зрада повсталому народові (асоційованому з гетьманською адміністрацією), невиконання наказових вимог старшинської адміністрації, ненадання допомоги під час бою. Усі ці склади злочинних дій у новій правовій реальності зазвичай каралися смертю, що піддається поясненню умовами перманентної війни за незалежність.

Остання чверть XVII-го ст. і фактично все XVIII ст. вітчизняної історії пройшли у загальному руслі занепаду козацько-гетьманської держави. Ця тенденція найбільш зримо виявила себе насамперед у поступовій відмові українських владних інституцій (але - не народних мас! - Abm.) під тиском російського самодержавства від революційних завоювань часів «Хмельниччини» у соціальній та політичній сферах, а також зміною домінантів у застосуванні доморощеного та нав'язаного ззовні права.

Це знаходило свій вияв у такому:

По-перше, автономію правового життя України і своєрідність ії правового укладу в період від початку Національної революції аж до кінця XVIII ст. передусім визначала обставина, що полягала у збереженні за населенням Гетьманщини права користуватися своїми «давніми», «старовинними» або традиційними юридичними нормами. Такий стан речей справді, погодимося 3 С. Ковальовою, був важливою запорукою, не тільки для литовсько-руського, але й для козацького суспільства, збереження «існування звичного порядку речей, суспільної стабільності та безпеки» ${ }^{12}$. Підтвердженням цього було зокрема те, що формальне збереження в Украйні-Гетьманщині «давніх прав і

12 Ковальова С. Г. Принцип старовини у правосвідомості литовсько-руського суспільства (XIV -XVI ст.). Науковий вісник Ужгородського національного університету. Серія Право. 2017. Вип. 45. Т.1. С. 14. 
вольностей» або «попередніх прав» неодноразово - на нашу думку, вимушено - підтверджувалося центральною російською владою. Формула непорушності «малоросійських прав» стала загальним правилом гетьманських договірних статей другої половини XVII ст. - початку XVIII ст. Разом із цим, з цією визнаємо - юридичною фікцією були вимушені погоджуватися навіть великодержавницькі московські сили. Навіть у визначено спрямованих на обмеження самоврядування в Україні указах Петра I згадуються про т. зв. «попередні права».

По-друге, за нових - московсько-автономістичних - історичних умов автономне право Гетьманщини використовувалося тепер для закріплення інтересів нового привілейованого стану тогочасного суспільства - козацтва i, передусім, його верхніх щаблів - козацької старшини. Остання домагалася створення на міцній правовій основі централізованої системи підпорядкування, поширення й закріплення за собою володіння земельною власністю та права на працю залежних селян.

Це робилося, зокрема, під виглядом нібито відновлення «давніх прав i вольностей». У цьому українську старшину підтримували й гетьмани, й російський царизм. У судовій практиці, в процесах останньої чверті XVII-XVIII ст. практики дедалі частіше стали посилатися на правові джерела польськолитовської доби. Відтак Литовський Статут і збірники Магдебурзького права в більшості офіційних документів почали визначатися як обов'язкові.

Позаяк, численні дослідники (зокрема, О. Гуржій, Т. Чухліб) у розвитку права Гетьманщини вбачають колізію, що полягала саме у формулі «попередніх прав»13. Річ у тому, що представники різних станів і соціальних груп Гетьманщини при застосуванні формули «давніх», «стародавніх» прав, переслідуючи власні інтереси, далеко не однаково їх трактували. Так, українська шляхта і старшина під «колишніми правами» розуміли звичний порядок і правовий статус правлячої верхівки до 1648 року, що головно базувався на Литовському статуті та збірниках Магдебурзького права. Натомість селяни й рядові (не належні до козацької старшини - Abm.) козаки, навпаки, ототожнювали «давні права» 3 тими правовими нормами, котрі утвердилися у Запорозькій Січі, й відкидали кріпосницькі відносини між людьми.

${ }^{13}$ Гуржій O. Українська козацька держава в другій половині XVII-XVIII ст.: Кордони, населення, право. К.: Основи, 1996. 222 с.; Гуржій О. І., Чухліб Т. В. Гетьманська Україна. К.: Видавничий дім “Альтернативи”, 1999. - 304 с. 
Висновки. Отже, козацьке право - цивілізаційне явище, невід'ємне від Козацької держави, суто український національний політико-правовий феномен, апогей еволюції якого припадає на часи існування Гетьманщини. Вирішальним впливом на правову систему Хмельниччини періоду становлення козацько-гетьманської держави слугував цивілізаційний вибір представників усіх суспільних верств тогочасного населення земель під гетьманською юрисдикцією на користь закріплення основних засад «козацької», фактично ж прото-лібертаріанської (термін «лібертаріанство з'явився багато пізніше, аж у XIX ст. - Abm.), філософії й, відповідно, зміну соціальної сутності права. У цьому відношенні, на нашу думку, населення Гетьманщини не стільки випередило свій історичний час (добуржуазних суспільних відносин), скільки інтуїтивно поєднало власне «хочу» 3 імперативним «маю», «повинен».

Dr. habil. Prof. Volodymyr Makarchuk (Lviv, Ukraine)

PhD in History Ivan Terlyuk (Lviv, Ukraine)

Cossack Law of the Hetmanate as a Special Political and Legal Phenomenon

Cossack law is investigated as a civilization phenomenon of Ukrainian history and a purely Ukrainian national political and legal phenomenon, inseparable from the Cossack state, the apogee of the evolution of which belongs to the times of the Hetmanate. It is emphasized that the origins of the process of origination of Ukrainian law itself, that is, the time when its original difference from the rights of neighbouring states - Polish, Moscow, Ottoman, etc. - was laid down, belongs to the period of the Hetmanate (in particular, its initial stage of Khmelnytsky War). The thesis is argued that the decisive influence on the formation of the Ukrainian legal system at that time was the civilizational choice of representatives of all social strata of the population of the lands under hetman jurisdiction in favour of consolidating the basic principles of the «Cossack philosophy» of a peculiar system of values in the arrangement, equity, equality and public interest. Arguments are presented indicating the beginning of a new quality of Ukrainian Cossack law - in contrast to the former corporate one, it is becoming a sign of Ukrainian national law because of a change in social nature. And this quality, in general, could not be undermined by the changes of the dominant in the application of the homegrown and externally imposed rights that fell to the decline of the Cossack-Hetman state, the last quarter of the 17-th and, in fact, all of the 18-th national history. It is concluded that one of the consequences of the Cossack influence on legal relations was the fact that the population of the Hetman region actually outstripped its historical time of bourgeois social relations. 
Key words: Cossack law, Cossack state, Khmelnytskyi's period, Cossack's Hetmanate.

Доктор юридических наук Владимир Макарчук (Львов, Украина)

Кандидат исторических наук Иван Терлюк (Львов, Украина)

Казацкое право Гетманщины как особенный политико-правовой феномен Исследуется казацкое право, как цивилизационное явление украинской истории и сугубо украинский национальный политико-правовой феномен, неотделимый от Казацкой державы, апогей эволюции которой приходится на времена существования Гетманщины. Подчеркивается, что истоки процесса зарождения собственно украинского права, то есть время, когда было заложено его первоначальное (изначальное) отличие от права соседних государств польского, московского, османского т. Д. - приходится на период Гетьманщины (в частности ее начального этапа - Хмельниччины). Обосновывается тезис о том, что решающее влияние на формирование тогдашней украинской правовой системы составил цивилизационный выбор представителей всех общественных слоев тогдашнего населения земель гетманской юрисдикции в пользу закрепления основных принципов «казацкой философии» своеобразной системы ценностей в обустройстве общественной жизни, которая основывалась на идеях свободы, справедливости, равноправия и общественного интереса. Приводятся аргументы, свидетельствующие о начале нового качества украинского казацкого права - в противовес прежнему корпоративному через изменение социальной сущности - оно приобретает признаки украинского национального права. И это его качество в целом не смогли поколебать изменения доминантов в применении доморощенного и навязанного извне права, которые приходятся на упадок казацко-гетманского государства, последнюю четверть XVII-го века и фактически весь XVIII век отечественной истории. Делается вывод, что одним из последствий казацкого влияния на правовые отношения стало фактическое опережение населением Гетманщины своего исторического времени - добуржуазных общественных отношений.

Ключевые слова: казацкое право, казацкое государство, Хмельниччина, Гетманщина. 
Доктор юридичних наук Володимир Макарчук (Львів, Україна) Кандидат історичних наук Іван Терлюк (Львів, Україна)

Козацьке право Гетьманщини як особливий політико-правовий феномен Досліджується козацьке право як цивілізаційне явище української історії й суто український національний політико-правовий феномен, невіддільний від Козацької держави, апогей еволюції якої припадає на часи існування Гетьманщини. Наголошується на тому, що витоки процесу зародження власне українського права, тобто час, коли було закладено його первісну (споконвічну) відмінність від права сусідніх держав - польського, московського, османського тощо - припадає на період Гетьманщини (зокрема їі початкового етапу - Хмельниччини). Обгрунтовується теза про те, що вирішальним впливом на формування тогочасної української правової системи слугував цивілізаційний вибір представників усіх суспільних верств тогочасного населення земель під гетьманською юрисдикцією на користь закріплення основних засад «козацької філософії» - своєрідної системи цінностей в облаштуванні суспільного життя, що засновувалася на ідеях свободи, справедливості, рівноправності та громадського інтересу. Наводяться аргументи, що свідчать про започаткування нової якості українського козацького права - на противагу колишньому корпоративному через зміну соціальної сутності - воно набуває ознак українського національного права. I цю його якість загалом не змогли похитнути зміни домінантів у застосуванні доморощеного та нав'язаного ззовні права, що припадають на занепад козацько-гетьманської держави - останню чверть XVII-го ст. та фактично усе XVIII ст. вітчизняної історії. Робиться висновок, що одним 3 наслідків козацького впливу на правові відносини було фактичне випередження населенням Гетьманщини свого історичного часу - добуржуазних суспільних відносин.

Ключові слова: козацьке право, козацька держава, Хмельниччина, Гетьманщина.

* Макарчук Володимир Степанович - доктор юридичних наук, професор, професор кафедри теорії, історії та філософії права Інституту права, психології та інноваційної освіти Національного університету «Львівська політехніка»

* Терлюк Іван Ярославович - кандидат історичних наук, доцент, доцент кафедри історії держави та права Навчально-наукового інституту права та психології Національного університету «Львівська політехніки».

E-mail: mvs6043@ukr.net. 